\title{
Role of a large marine protected area for conserving landscape attributes of sand habitats on Georges Bank (NW Atlantic)
}

\author{
James Lindholm ${ }^{1,3, *}$, Peter Auster ${ }^{1}$, Page Valentine ${ }^{2}$ \\ ${ }^{1}$ National Undersea Research Center at the University of Connecticut, 1080 Shennecossett Rd., Groton, Connecticut 06340, USA \\ ${ }^{2}$ US Geological Survey, 384 Woods Hole Road, Woods Hole, Massachusetts 02543, USA
}

${ }^{3}$ Present address: Pfleger Institute of Environmental Research, 901-B Pier View Way, Oceanside, California 92054, USA

\begin{abstract}
Mobile fishing gear reduces seafloor habitat complexity through the removal of structure-building fauna, e.g. emergent organisms that create pits and burrows, as well as by smoothing of sedimentary bedforms (e.g. sand ripples). In this study, we compared the relative abundance of microhabitat features (the scale at which individual fish associate with seafloor habitat) inside and outside of a large fishery closed area $\left(6917 \mathrm{~km}^{2}\right)$ on Georges Bank. Starting in late 1994, the closed area excluded all bottom tending fishing gear capable of capturing demersal fishes. A total of 32 stations were selected inside and outside of the closed area in sand habitats. Video and still photographic transects were conducted at each station using the Seabed Observation and Sampling System (SEABOSS). Seven common (i.e. featureless sand, rippled sand, sand with emergent fauna, bare gravelly sand, gravelly sand with attached-erect fauna, whole shell, shell fragment) and 2 rare (sponges, biogenic depressions) microhabitat types were compared separately. Results showed significant differences in the relative abundance of the shell fragment and sponge microhabitat types between fished and unfished areas. The lack of differences for the other microhabitats may indicate that the level of fishing activity in the area is matched by the system's ability to recover.
\end{abstract}

KEY WORDS: Microhabitat $\cdot$ Fishing gear $\cdot$ Fishing impacts $\cdot$ Photography $\cdot$ Video Resale or republication not permitted without written consent of the publisher

\section{INTRODUCTION}

Fishing has been described as the dominant direct anthropogenic impact to marine ecosystems worldwide (Dayton et al. 1995). One significant type of impact is the effect of mobile bottom-contact fishing gear (e.g. scallop dredges, bottom trawls) on seafloor habitat and associated taxa (Jennings \& Kaiser 1998, Auster \& Langton 1999, Hall 1999, Collie et al. 2000, National Research Council 2002). Mobile fishing gear reduces seafloor habitat complexity through the removal of attached and emergent fauna that provide structure (e.g. erect sponges and burrowing anemones), the removal of structure-building megafauna that produce pits and burrows (e.g. crabs, fish) and the smoothing of bedforms (e.g. sand waves) (Auster et al. 1996).
Small-scale variation in the distribution and abundance of demersal fishes can be attributed in part to habitat attributes (i.e. structural complexity, prey type and abundance) on the seafloor (Langton et al. 1995). The reduction in seafloor habitat complexity has been shown to increase the mortality of early demersalphase juvenile fish, such as Atlantic cod Gadus morhua, that utilize the structure provided by emergent fauna and physical substrata for protection from predation (Lindholm et al. 1999). Modeling studies have demonstrated that such habitat-mediated mortality of juvenile fish can have significant population-level effects (Lindholm et al. 1998, 2001). The distribution of demersal fishes has been correlated with a variety of structural habitat features from piled boulder reefs to highdensity patches of amphipod tubes (Auster et al. 1997, 
1998, 2003). The use of no-take marine protected areas has been suggested as a way to conserve the attributes of ecosystems that can sustain exploited fish populations (Auster \& Shackell 2000, National Research Council 2001).

Georges Bank (northwest Atlantic) is a topographic high located along the shelf-slope boundary between the Gulf of Maine to the north and the Atlantic Ocean (see Fig. 1). The bank has supported high levels of fishing activity for demersal fishes such as Atlantic cod, haddock Melanogrammus aeglefinus, and yellowtail flounder Limanda ferruginea for more than $500 \mathrm{yr}$ (Lear 1998). Mobile bottom-contact fishing gear, specifically, has been used to exploit fish populations on Georges Bank for 92 yr (Lear 1998). Although not designated specifically for habitat protection, the large closure on eastern Georges Bank called Closed Area II $\left(6917 \mathrm{~km}^{2}\right.$ ) provided the opportunity to compare the relative abundance of sand microhabitats (the scale at which individual fish associate with seafloor habitat) in an area closed to fishing with adjacent fished areas.

\section{MATERIALS AND METHODS}

A cruise was conducted in June 1999 to assess the status of seafloor microhabitats in the southern part of Closed Area II approximately $4.5 \mathrm{yr}$ after closure (see Fig. 1 inset; south of $41^{\circ} 30^{\prime} \mathrm{N}$ where seafloor habitats are primarily sand). A total of 32 stations (50 to $100 \mathrm{~m}$ water depth) were located inside and outside of the closed area (see Fig. 1). All unfished stations were located a minimum of $5.6 \mathrm{~km}$ inside the closed area to minimize the possibility that any fishing activity impacted those sites.

A single combined video and still photographic transect was conducted at each station using the Seabed Observation and Sampling System (SEABOSS; Blackwood \& Parolski 2001). The system has 2 video cameras (forward and down-looking), a down-looking $35 \mathrm{~mm}$ camera, and 3 down-looking lasers for image calibration and estimating height off the bottom. Quartz halogen lights provided illumination for the video, and an electronic flash unit provided lighting for still photographs. The system was tethered to the suport vessel with an electro-mechanical cable for streaming video imagery and controlling camera functions and altitude in real time, and drifted over each station.

Each transect consisted of $20 \mathrm{~min}$ of continuous video recorded on Hi-8 format videotape and 20 still photographs. Still photographs were taken at approximately 1 min intervals throughout each transect to assess the relative abundance of 'common' microhabitat types (i.e. featureless sand, rippled sand, sand with emergent fauna, bare gravelly sand, gravelly sand with attached-erect fauna, whole shell, shell fragment). Additional photographs were taken to document habitat features and organisms and were not used for quantitative analyses. Down-looking video was quantified for computing the relative abundance of 'rare' habitat types (i.e. sponges, biogenic depressions). Note that the term rare is used in the numerical sense based on under-representation in the photographs rather than in a population sense. Paired parallel lasers (20 cm spacing) and a third crossing laser were used to indicate a consistent height for taking still photographs (to maintain constancy in area of coverage for each image) and for maintaining altitude for video transects. Still photographs were taken from a height of approximately $0.75 \mathrm{~m}$ off the seafloor and covered an area of approximately $0.39 \mathrm{~m}^{2}$.

Data on the percent relative abundance of 7 common microhabitats were derived from images using a classification system based on abiotic and biotic seafloor features that fishes have been shown to use for cover (Auster et al. 1995, 1998, Auster 1998). Data were produced from the still photographs using a series of 20 randomly distributed dots overlaid on each photograph. The microhabitat feature under each dot was counted and apportioned to a particular habitat type. New random patterns were used in a transect for each photograph. The percent relative abundance of a given microhabitat was calculated as the number of each habitat type divided by the total number of occurrence for all microhabitats for that transect.

Imagery from the down-looking video camera was used to characterize the relative abundance of rare microhabitats (i.e. emergent sponges and biogenic depressions created by scallops, fish and crabs). These 2 microhabitat types were not well represented by the still photographs (less than $0.01 \%$ of all observations) and were subsequently removed from the analysis of still photographs. However, both sponges and depressions were obviously present from qualitative viewing of the video. Each video transect was treated as a series of non-overlapping video frames (sensu Auster et al. 1991). The size of a down-looking video frame at a height of $0.75 \mathrm{~m}$ from the seafloor was $1.14 \mathrm{~m}^{2}$. The relative abundances for sponges and depressions were calculated based on the number of video frames in which the microhabitat type occurred divided by the transect distance in meters (i.e. frames $\mathrm{m}^{-1}$ ).

Statistical assumptions that underlie parametric analyses were tested using the Ryan-Joiner test of normality. All data were arcsine transformed to insure normality. Separate analyses were conducted with data derived from still and video imagery. Linear regression was used to explore the relationship between microhabitats and water depth. A 2-way ANOVA was 
conducted to identify any effect of Closed Area II, water depth, and the closure-depth interaction, on the relative abundance of common and rare microhabitats.

\section{RESULTS}

Analysis of the common microhabitats from still photographs (Table 1) indicated that the stations included in this study, both inside and outside of Closed Area II, were dominated by sand with emergent fauna, with mean percent relative abundance of 47.18 and $38.21 \%$, respectively. This microhabitat type consisted largely of tubes emerging approximately $2 \mathrm{~cm}$ above the sediment-water interface, created by tube-forming amphipods and worms. Featureless sand was the next most abundant microhabitat for each treatment, with $33.28 \%$ mean relative abundance inside the closed area and $34.73 \%$ mean relative abundance outside. The shell fragment microhabitat, with $14.68 \%$ inside and $11.90 \%$ outside, was the third most abundant, with the remaining 4 microhabitats each present in less than $3 \%$ of the observations. Analysis of video records (Table 2) indicated that biogenic depressions were more abundant, both inside (mean relative abundance $=16.58$ video frames $\mathrm{m}^{-1}$ ) and outside (mean relative abundance $=8.96$ video frames $\mathrm{m}^{-1}$ ) the closed area, than were sponges (less than 2 video frames $\mathrm{m}^{-1}$ both inside and outside).

The northwest portion of the study area (Fig. 1) was located at depths shallower than $60 \mathrm{~m}$ water depth. At this depth, the bottom was characterized as mobile sand, where tidal and stormdriven currents regularly impact the bottom. Not surprisingly, the rippled sand microhabitat $\left(\mathrm{r}^{2}=0.272, \mathrm{p}=0.002\right)$ appeared to be more abundant at depths shallower than the $60 \mathrm{~m}$ isobath. The remainder of the study area was at greater than $60 \mathrm{~m}$ water depth, and was characterized by immobile, or stable sands, below the common depth of storm-generated turbulence and current (Valentine unpubl. obs.). Both the featureless sand microhabitat $\left(\mathrm{r}^{2}=0.562\right.$, $\mathrm{p}=0.000$ ) and the sand with emergent fauna microhabitat appeared to be more abundant in this less-disturbed environment $\left(r^{2}=0.578, p=0.000\right)$. Regressions for 3 of the 7 common microhabitat types (Fig. 2A,B,C) were highly significant $(\alpha=0.05)$, indicating that water depth was an important factor in the abundance of those microhabitats. Re-
Table 1. Mean percent relative abundance of common microhabitat types from still photographs inside and outside of Closed Area II

\begin{tabular}{|c|c|c|}
\hline \multirow[t]{2}{*}{ Microhabitat type } & \multicolumn{2}{|c|}{$\begin{array}{c}\text { Mean } \\
\% \text { relative } \\
\text { abundance }\end{array}$} \\
\hline & Inside & Outside \\
\hline Featureless sand & 33.28 & 34.73 \\
\hline Rippled sand & 00.46 & 00.71 \\
\hline Sand with emergent fauna & 47.18 & 38.21 \\
\hline $\begin{array}{l}\text { Gravelly sand without } \\
\text { attached-erect fauna }\end{array}$ & 00.41 & 00.75 \\
\hline $\begin{array}{l}\text { Gravelly sand with } \\
\text { attached-erect fauna }\end{array}$ & 00.00 & 01.85 \\
\hline Bivalve/whole shell & 02.68 & 01.17 \\
\hline Shell fragment & 14.68 & 11.90 \\
\hline
\end{tabular}

Table 2. Mean relative abundance (number of video frames $\mathrm{m}^{-1}$ ) of rare microhabitat types from video inside and outside of Closed Area II

\begin{tabular}{|lcc|}
\hline \multirow{2}{*}{ Rare } & \multicolumn{2}{c|}{ Mean relative } \\
microhabitat type & \multicolumn{2}{c|}{ abundance } \\
& Inside & Outside \\
\hline Biogenic depression & 16.58 & 08.96 \\
Sponges & 01.57 & 00.28 \\
\hline
\end{tabular}

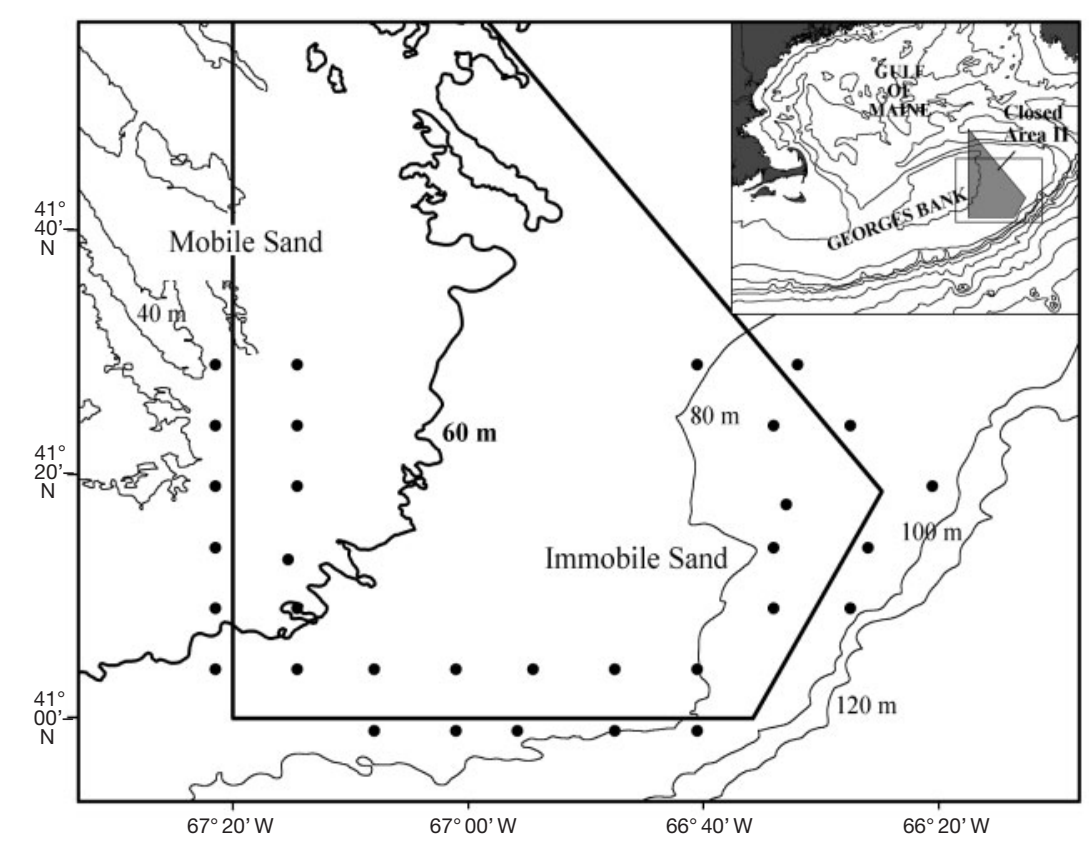

Fig. 1. Map of Closed Area II on Georges Bank illustrating the location of 32 sampling stations (16 inside the closure and 16 outside). Microhabitats in mobile sand occurred in $<60 \mathrm{~m}$ water depth (bold isobath) while immobile sand occurred at depths $>60 \mathrm{~m}$ 

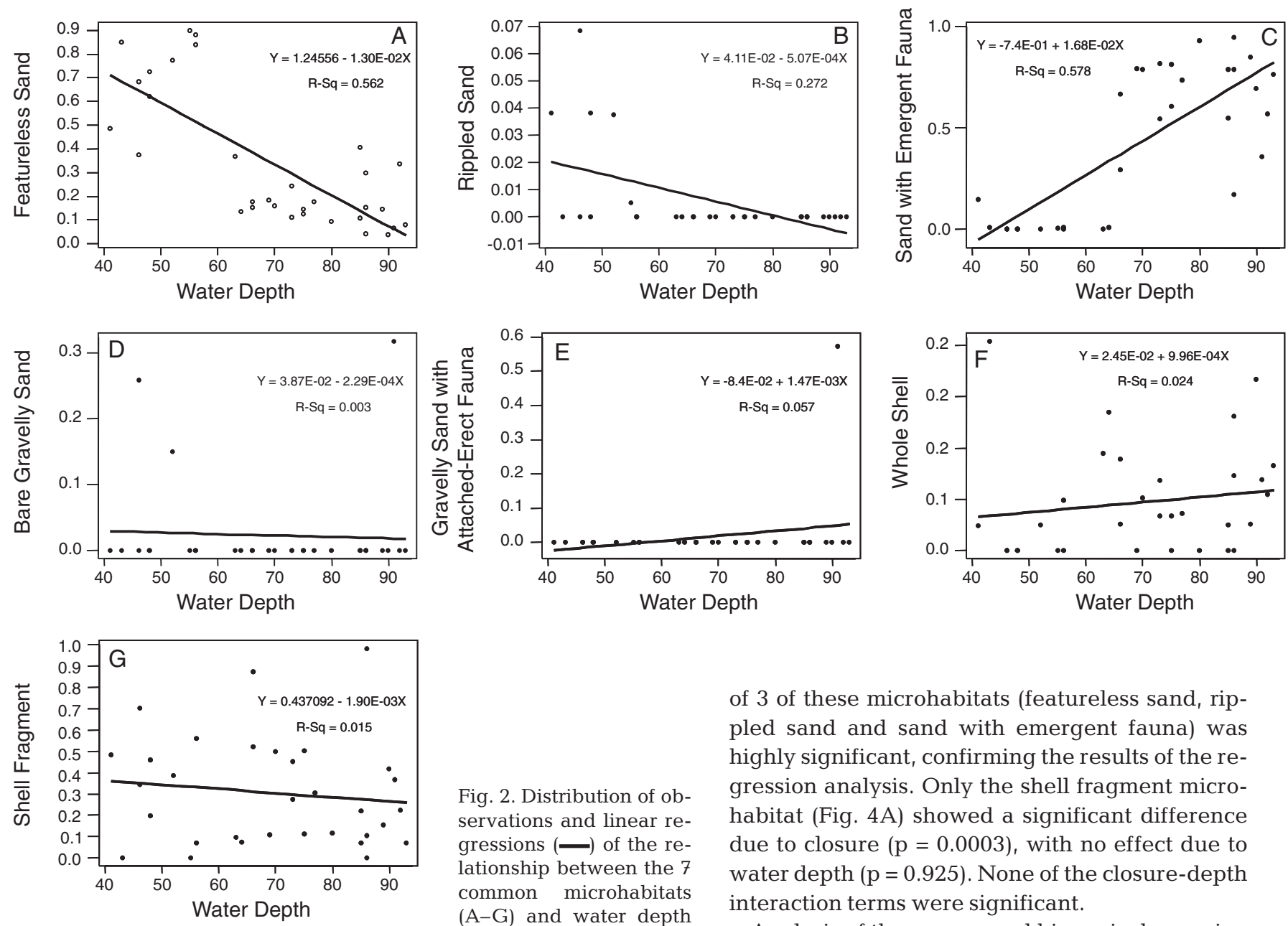

of 3 of these microhabitats (featureless sand, rippled sand and sand with emergent fauna) was highly significant, confirming the results of the re-

Fig. 2. Distribution of observations and linear regressions (-) of the relationship between the 7 common microhabitats (A-G) and water depth sults for the other 4 common microhabitats (Fig. 2D-G), and the 2 rare microhabitats (Fig. 3), were not significant with respect to water depth.

Results of the 2-way ANOVA for the common microhabitats from the still photographs are provided in Table 3. Six of the 7 microhabitats showed no effect of the closed area on mean percent relative abundance. The effect of depth on mean percent relative abundance gression analysis. Only the shell fragment microhabitat (Fig. 4A) showed a significant difference due to closure $(\mathrm{p}=0.0003)$, with no effect due to water depth $(p=0.925)$. None of the closure-depth interaction terms were significant.

Analysis of the sponge and biogenic depression microhabitats (Table 4) derived from the video data indicated that sponges (Fig. 4B) were marginally more abundant (where marginally significance $=p$ value $>0.05$ and $<0.10$ ) both inside the closed area $(p=0.073)$ and in deeper water $(p=0.059)$. No differences in the abundance of biogenic depressions were attributed to the closed area, though both the depth $(p=0.013)$ and closure-depth interaction $(p=0.019)$ terms were significant.
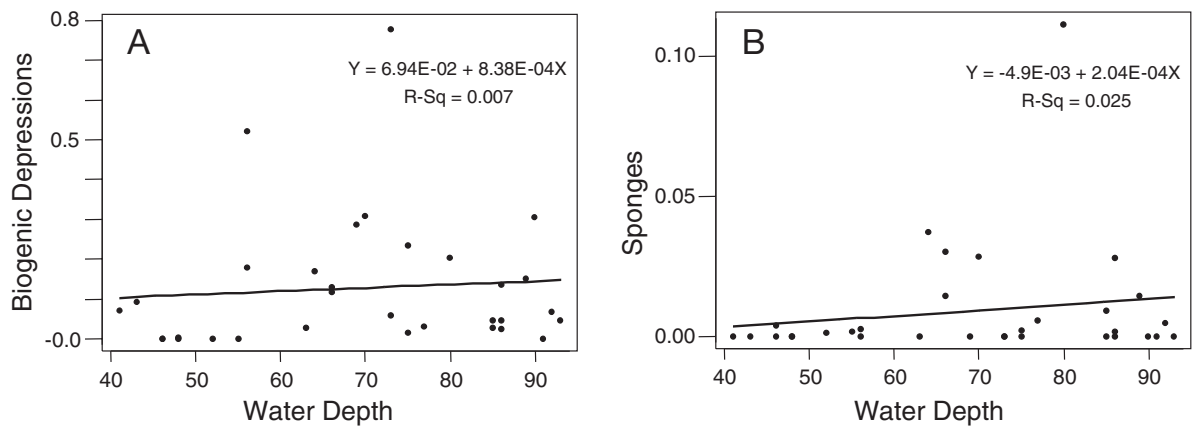

Fig. 3. Distribution of observations and linear regressions (-) of the relationship between the 2 rare microhabitats (A and B) and water depth 
Table 3. Results of 2-way ANOVA used to test for effects of Closed Area II, water depth and closure-water depth interaction on abundance of common microhabitats from still photographs $(\mathrm{n}=32)$

\begin{tabular}{|c|c|c|c|c|}
\hline Source & $\mathrm{df}$ & Mean square & $F$ & $\mathrm{p}$ \\
\hline \multicolumn{5}{|l|}{ Featureless sand } \\
\hline Closure & 1 & 0.00043 & 0.02 & 0.896 \\
\hline Depth & 1 & 2.56930 & 103.35 & 0.000 \\
\hline Closure $\times$ depth & 1 & 0.01953 & 0.79 & 0.383 \\
\hline Error & 28 & 0.02486 & & \\
\hline \multicolumn{5}{|l|}{ Rippled sand } \\
\hline Closure & 1 & 0.00431 & 1.22 & 0.278 \\
\hline Depth & 1 & 0.05883 & 16.70 & 0.000 \\
\hline Closure $\times$ depth & 1 & 0.00431 & 1.22 & 0.278 \\
\hline Error & 28 & 0.00352 & & \\
\hline \multicolumn{5}{|c|}{ Sand with emergent fauna } \\
\hline Closure & 1 & 0.0251 & 0.28 & 0.598 \\
\hline Depth & 1 & 4.6821 & 53.00 & 0.000 \\
\hline Closure $\times$ depth & 1 & 0.0835 & 0.95 & 0.339 \\
\hline Error & 28 & 0.0883 & & \\
\hline \multicolumn{5}{|l|}{ Bare gravelly sand } \\
\hline Closure & 1 & 0.00009 & 0.01 & 0.904 \\
\hline Depth & 1 & 0.00485 & 0.83 & 0.370 \\
\hline Closure $\times$ depth & 1 & 0.00441 & 0.75 & 0.393 \\
\hline Error & 28 & 0.00585 & & \\
\hline \multicolumn{5}{|c|}{$\begin{array}{l}\text { Gravelly sand with } \\
\text { attached-erect fauna }\end{array}$} \\
\hline Closure & 1 & 0.00469 & 0.44 & 0.514 \\
\hline Depth & 1 & 0.00469 & 0.44 & 0.514 \\
\hline Closure $\times$ depth & 1 & 0.00469 & 0.44 & 0.514 \\
\hline Error & 28 & 0.31966 & & \\
\hline \multicolumn{5}{|l|}{ Whole shell } \\
\hline Closure & 1 & 0.00816 & 0.69 & 0.412 \\
\hline Depth & 1 & 0.01605 & 1.37 & 0.252 \\
\hline Closure $\times$ depth & 1 & 0.00044 & 0.04 & 0.849 \\
\hline Error & 28 & 0.01175 & & \\
\hline \multicolumn{5}{|l|}{ Shell fragment } \\
\hline Closure & 1 & 0.45401 & 10.77 & 0.003 \\
\hline Depth & 1 & 0.00038 & 0.01 & 0.925 \\
\hline Closure $\times$ depth & 1 & 0.00469 & 0.39 & 0.538 \\
\hline Error & 28 & 0.04217 & & \\
\hline
\end{tabular}
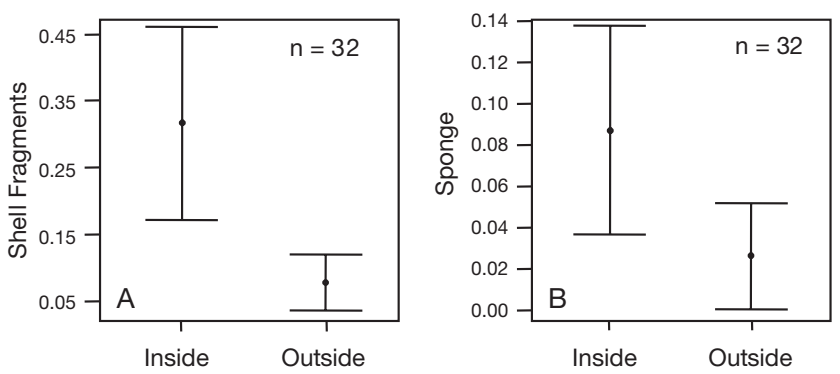

Fig. 4. Comparison of the sponge and shell fragment microhabitats inside and outside of Closed Area II after $4.5 \mathrm{yr}$ of closure (arcsine transformed). Means are reported with $95 \%$ confidence intervals
Table 4. Results of 2-way ANOVA used to test for effects of Closed Area II, water depth, and closure-water depth interaction on abundance of rare microhabitats from video $(\mathrm{n}=32)$

\begin{tabular}{|lrccc|}
\hline Source & df & Mean square & $F$ & $\mathrm{p}$ \\
\hline Sponge & & & & \\
$\quad$ Closure & 1 & 0.01802 & 3.46 & 0.073 \\
$\quad$ Depth & 1 & 0.02016 & 3.87 & 0.059 \\
$\quad$ Closure $\times$ Depth & 1 & 0.00477 & 0.91 & 0.347 \\
$\quad$ Error & 28 & 0.00521 & & \\
Biogenic depression & & & & \\
$\quad$ Closure & 1 & 0.00099 & 0.02 & 0.886 \\
$\quad$ Depth & 1 & 0.33200 & 7.00 & 0.013 \\
$\quad$ losure $\times$ Depth & 1 & 0.29443 & 6.21 & 0.019 \\
$\quad$ Error & 28 & 0.04743 & & \\
\hline
\end{tabular}

\section{DISCUSSION}

This study demonstrated that there were measurable differences in microhabitat resources between fished and unfished sites on Georges Bank after 4.5 yr of closure, and that depth is an important factor in the abundance of microhabitats in predominantly sandy landscapes. Sponge microhabitats, numerically rare based on our sampling methods, were more abundant inside Closed Area II, as were shell fragment microhabitats. However, no differences were detected due to the closed area for the other 6 common microhabitat categories and biogenic depressions. The lack of measurable effects, despite significant fishing outside the closed area, is attributed to the dynamic physical environment and the life histories of structure forming fauna that are adapted to such conditions.

The majority of the significant and nonsignificant results in the distributions of microhabitat resources are consistent with previous studies of fishing-mediated disturbance. With sedimentary structures such as rippled sand and featureless sand, the observed lack of difference due to the closed area, as well as the significant difference due to depth, could be predicted from models of active sediment transport where tidal and storm induced currents re-sort sands and restore structural elements to sand landscapes during short time periods (DeAlteris et al. 1999). Similar results would be expected for sand with emergent fauna, where tube forming amphipods and other emergent fauna would not be expected to settle in such a disturbed environment. The nonsignificant differences in cover provided by sand with emergent fauna, inside and outside of the closed area, can be attributed to immigration into disturbed patches or widespread recruitment events (Michael 1987, Auster \& Langton 1999).

The significant differences observed for sponge microhabitat are consistent with studies that found recovery rates of such taxa are low due to aperiodic 
recruitment and slow growth (Witman \& Sebens 1990). Similar patterns in structure forming fauna were found in the Bering Sea where particular taxa (e.g. sponges) were more abundant in unfished areas when compared to areas that were subject to disturbance by trawling (McConnaughey et al. 2000). Suberites ficus attach to or settle on small fragments of shell and can extend up to $35 \mathrm{~cm}$ in length and $10 \mathrm{~cm}$ in width (Weiss 1995). Either fully erect, or lying on their side, these sponges have been observed to provide cover for fish and crustaceans (Auster et al. 1991). They are vulnerable to mobile fishing gear and, if present, are common components of trawl and scallop dredge catches. They generally are discarded overboard but their rates of mortality are unknown.

The presence of shell fragments can be a consequence of fishing with mobile gear through direct breakage of live bivalves, post impact predation of damaged animals, or direct breakage of individual valves (Meyer et al. 1981, Shepard \& Auster 1991). However, shell fragments can also be the result of predation, principally by crustaceans and skates (McEachran et al. 1976, Boulding 1984, Bowman et al. 2000). The higher abundance of shell fragments (primarily Arctica islandica) inside the closed area (Fig. 4A) is not consistent with what we would expect to occur following $4.5 \mathrm{yr}$ of closure if fishing were the mediating factor. While the mean percent relative abundance for each treatment $(14.68 \%$ inside and $11.9 \%$ outside) is statistically significant, the overall difference in cover is low. No data were available on the status of megafaunal crustacean numbers (e.g. crabs and lobsters) inside and outside the closed area. However, abundance and biomass of all skate species was greater outside the closed area (Link et al. in press), suggesting that inferences about spatial patterns of predation from elasmobranches will not explain the observed patterns of shell fragments either.

The timing, severity and frequency of fishing gear impacts all interact to mediate processes that lead to recovery (Watling \& Norse 1998, Auster \& Langton 1999). The lack of significant differences in the relative abundance of most of the common microhabitat resources inside and outside of Closed Area II may be interpreted as a consequence of the level of fishing effort matching the ability of the ecosystem to accommodate human-caused disturbances over short time periods. At the time of this study, approximately 250 vessels (89\% scallop dredges and 10\% otter trawls) targeted scallops year round on the US side of the US-Canadian boundary on Georges Bank and in the Mid-Atlantic Bight (NMFS 2002). Scallop fishing effort on the US side of eastern Georges Bank, as determined by vessel monitoring systems on board each vessel, was concentrated in the areas immediately adjacent to the south and west of the closed area in the 2 yr (1998 and 1999) prior to our sampling (NMFS 2002). This effort was distributed across fished sites in both mobile and immobile sand habitats.

It is possible that mobile sand habitats that experience varying degrees of sand movement naturally are able to recover from the impact of bottom fishing gear in a relatively short period of time, perhaps less than a year. For example, Fig. 5 shows the contrast in habitat structure between an impacted and an adjacent reference area immediately after a single pass of a scallop dredge in immobile sand habitat south of Closed Area II. However, we did not observe such contrasting effects at any of the pre-selected stations adjacent to the closed area. (The images were produced during ad hoc observations within $6 \mathrm{~h}$ after a scallop vessel was observed actively fishing.) Lack of such contrasts from the majority of the stations inside and outside the closed area, despite large amounts of fishing effort, further demonstrates that recovery of common microhabitat features occurs rapidly.

Understanding of the role of microhabitat resources in sand landscapes for enhancing survivorship of cold temperate and boreal outer continental shelf fishes comes from studies focused on a few species. Laboratory studies found Atlantic cod and American plaice Pleuronectes platessa gained significant energetic savings by sheltering from flow in sand ripples (Gerstner 1998, Gerstner \& Webb 1998). Field observations of silver hake Merluccius bilinearis in sand-wave habitats showed a positive relationship between the increasing size class and the sand-wave period (Auster et al. 2003). The distribution of young-of-the-year silver hake has also been positively correlated with highdensity patches of amphipod tubes (Auster et al. 1997). The color pattern of the fish suggested that amphipod tube patches may serve as cover as well as a source of prey. However, the population consequences of differences in predator success, prey capture and energetic savings for fishes utilizing the range of microhabitat resources as we described here, are unknown.

Natural disturbance, in the form of diurnal tidal currents and seasonal storm-driven currents, is a significant influence on the relatively shallow sandy habitats of the study area. The northwest part of the Closed Area II study area (Fig. 1) is shallower and experiences stronger bottom currents than the southeastern part of the area. In the northwest at less than $60 \mathrm{~m}$ water depth (mobile sand), the strongest monthly mean flows of near-bottom semidiurnal tidal currents reach speeds of $59 \mathrm{~cm} \mathrm{~s}^{-1}$ (Moody et al. 1994). Such current velocities have been observed to generate shifts in sand wave structure and distributions of shell fragments. Maximum tidal flows and storm wave currents in the closed area can be much stronger at this 

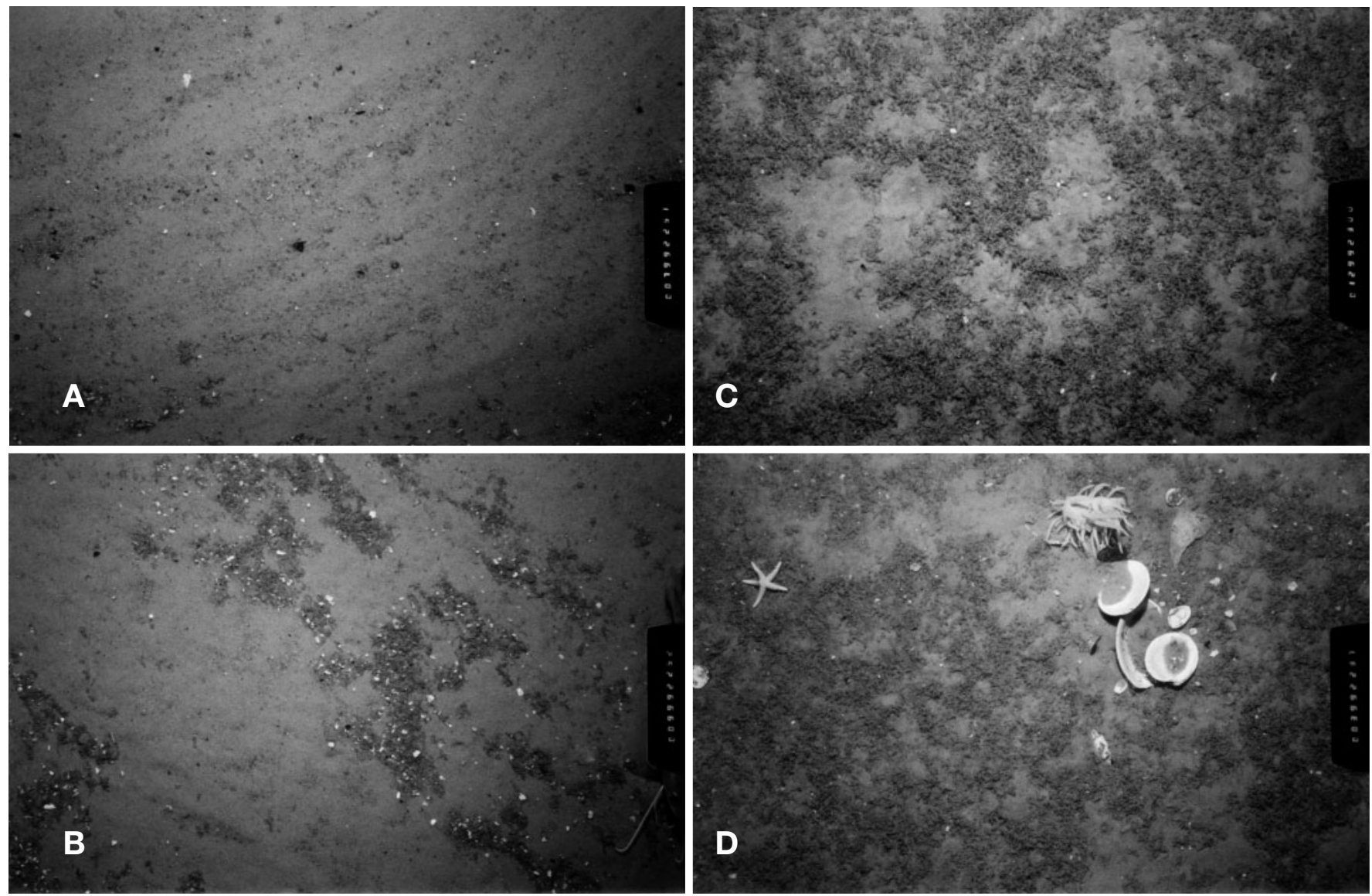

Fig. 5. Seafloor photographs taken while crossing a scallop dredge track south of Closed Area II in $79 \mathrm{~m}$ water depth. Observations were taken within $6 \mathrm{~h}$ of impact. The seafloor adjacent to the track (C and D) was composed of old storm generated bedforms with superimposed biogenic depressions. Emergent or attached-erect fauna along the dredge track (A and B) were removed or disrupted and the seafloor smoothed. Image size is approximately $51 \times 76 \mathrm{~cm}$

depth and explain the presence of crested sand structures (i.e. rippled sand and sand waves) that modify sand habitats. In contrast, in the southeast of the study area (immobile sand), at greater than $60 \mathrm{~m}$ water depth, maximum tidal flows reach speeds of less than $29 \mathrm{~cm} \mathrm{~s}^{-1}$ (Moody et al. 1994). Here the influence of tidal and less frequent storm-driven currents normally exert a much smaller influence on the microtopographic features of the seafloor, allowing longer lived structure-forming taxa such as sponges and other species of emergent fauna to persist in relatively higher numbers.

When considering habitat protection, grain size of sediments and oceanographic features may be used to make coarse predictions regarding the link between fishing effort and habitat attributes. For example, invertebrate communities in gravel habitats on the northeast peak of Georges Bank are sensitive to fishing gear disturbance, and have recovery times measured on the scale of a decade or more (Lough et al.
1989, Collie et al. 1997, 2000). In contrast, sand wave habitats contain a variety of features that most likely recover rapidly where oceanographic features like current patterns reshape sediment morphology and faunal life histories are adapted to high disturbance regimes (Auster \& Langton 1999, Collie et al. 2000, this study). A greater level of understanding of how marine communities respond to both human caused and natural disturbance regimes will be the only path to linking fishing disturbance with the resiliency of natural systems.

Acknowledgements. We would like to thank D. Blackwood and D. Nichols for assistance in the field with data collection and the operation of SEABOSS, as well as the crew of the NOAA ship 'Albatross IV'. This work was supported by the National Marine Fisheries Service, National Undersea Research Program, and the US Geological Survey. The views expressed herein are those of the authors and do not necessarily reflect the views of NOAA, USGS, or any of their subagencies. 


\section{LITERATURE CITED}

Auster PJ (1998) A conceptual model of the impacts of fishing gear on the integrity of fish habitats. Conserv Biol 12:1-6

Auster PJ, Langton RW (1999) The effects of fishing on fish habitat. In: Benaka L (ed) Fish habitat: essential fish habitat (EFH) and rehabilitation. American Fisheries Society, Bethesda, MD, p 150-187

Auster PJ, Shackell NL (2000) Marine protected areas for the temperate and boreal Northwest Atlantic: the potential for sustainable fisheries and conservation of biodiversity. Northeast Nat 7:419-434

Auster PJ, Malatesta RJ, LaRosa SC, Cooper RA, Stewart LL (1991) Microhabitat utilization by the megafaunal assemblage at a low relief outer continental shelf site-Middle Atlantic Bight, USA. J Northwest Atl Fish Sci 11:59-69

Auster PJ, Malatesta RJ, LaRosa SC (1995) Patterns of microhabitat utilization by mobile megafauna on the southern New England (USA) continental shelf and slope. Mar Ecol Prog Ser 127:77-85

Auster PJ, Malatesta RJ, Langton RW, Watling L and 5 others (1996) The impacts of mobile fishing gear on seafloor habitats in the Gulf of Maine (Northwest Atlantic): implications for conservation of fish populations. Rev Fish Sci 4:185-202

Auster PJ, Malatesta RJ, Donaldson CLS (1997) Distributional responses to small-scale habitat variability by early juvenile silver hake, Merluccius bilinearis. Environ Biol Fish 50:195-200

Auster PJ, Michalopoulos C, Valentine PC, Malatesta RJ (1998) Delineating and monitoring habitat management units in a temperate deep-water marine protected area. In: Munro NW, Willison JHM (eds) Linking protected areas with working landscapes, conserving biodiversity. Science and Management of Protected Areas Association, Wolfville, NS, p 169-185

Auster PJ, Lindholm J, Schaub S, Funnell G, Kaufman LS, Valentine PC (2003) Use of sand wave habitats by silver hake. J Fish Biol 62:143-152

Blackwood D, Parolski K (2001) Seabed observation and sampling system. Sea Technol Feb 42:39-43

Boulding EG (1984) Crab resistant features of shells of burrowing bivalves: decreasing vulnerability by increasing handling time. J Exp Mar Biol Ecol 76:201-223

Bowman RE, Stillwell CE, Michaels WL, Grosslein MD (2000) Food of northwest Atlantic fishes and two common species of squid.. NOAA Tech Memo NMFS-NE 155, p 1-138

Collie JS, Escanero GA, Valentine PC (1997) Effects of bottom fishing on the benthic megafauna of Georges Bank. Mar Ecol Prog Ser 155:159-172

Collie JS, Hall SJ, Kaiser MJ, Poiner IR (2000) A quantitative analysis of fishing impacts on shelf-sea benthos. J Anim Ecol 69:785-798

Dayton PK, Thrush SF, Agardy TM, Hofman RJ (1995) Environmental effects of fishing. Aquat Conserv 5:205-232

DeAlteris J, Skrobe L, Lipsky C (1999) The significance of seabed disturbance by mobile fishing gear relative to natural processes: a case study in Narragansett Bay, Rhode Island. Am Fish Soc Symp 22:224-237

Gerstner CL (1998) Use of substratum ripples for flow refuging by Atlantic cod, Gadus morhua. Environ Biol Fish 51:455-460

Gerstner CL, Webb PW (1998) The station-holding performance of plaice, Pleuronectes platessa, on artificial substratum ripples. Can J Zool 76:200-208

Hall SJ (1999) The effects of fishing on marine ecosystems and communities. Blackwell Science, Oxford

Jennings S, Kaiser MJ (1998) The effects of fishing on marine ecosystems. Adv Mar Biol 34:201-352

Langton RW, Auster PJ, Schneider DC (1995) A spatial and tem- poral perspective on research and management of groundfish in the northwest Atlantic. Rev Fish Sci 3:201-229

Lear WH (1998) History of fisheries in the northwest Atlantic: the 500-year perspective. J Northwest Atl Fish Sci 23:41-73

Lindholm J, Ruth M, Kaufman L, Auster PJ (1998) The marine refuge as a fishery management tool: a modeling approach to the design of marine refugia. In: Munro NW, Willison JHM (eds) Linking protected areas with working landscapes, conserving biodiversity. Science and Management of Protected Areas Association, Wolfville, NS, p 138-150

Lindholm J, Auster PJ, Kaufman L (1999) Habitat-mediated survivorship of juvenile (0-year) Atlantic cod (Gadus morhua). Mar Ecol Prog Ser 180:247-255

Lindholm J, Auster PJ, Ruth M, Kaufman L (2001) Modeling the effects of fishing and implications for the design of marine protected areas: juvenile fish responses to variations in seafloor habitat. Conserv Biol 15:424-437

Link J, Almeida F, Valentine P, Auster P, Reid R, Vitalano J (in press) The effects of area closures on Georges Bank. Am Fish Soc Symp

Lough RG, Valentine PC, Potter DC, Auditore PJ, Bolz GR, Neilson JD, Perry RI (1989) Ecology and distribution of juvenile cod and haddock in relation to sediment type and bottom currents on eastern Georges Bank. Mar Ecol Prog Ser 56: $1-12$

McConnaughey RA, Mier KL, Dew CB (2000) An examination of chronic trawling effects on soft-bottom benthos of the eastern Bering Sea. ICES J Mar Sci 57:1377-1388

McEachran JD, Boesch DF, Musick JA (1976) Food division within two sympatric species-pairs of skates (Pisces, Rajidae). Mar Biol 35:301-317

Meyer TL, Cooper RA, Pecci KJ (1981) The performance and environmental effects of a hydraulic clam dredge. Mar Fish Rev 43:14-22

Michael AD (1987) Variability of the benthic fauna, I: the New England outer continental shelf benchmark program, 1977. In: Backus RH (ed) Georges Bank. MIT Press, Cambridge, p 296-302

Moody JA, Butman B, Beardsley RC, Brown WS and 8 others (1994) Atlas of tidal elevation and current observations on the northeast American continental slope. US Geol Surv Bull 1611

National Research Council (2001) Marine Protected Areas. Tools for sustaining ocean ecosystems. National Academy Press, Washington, DC

National Research Council (2002) Effects of bottom trawling on seafloor habitats. National Academy Press, Washington, DC

NMFS (2002) Workshop on the effects of fishing gear on marine habitats off the northeastern United States, October 23-25, 2001 Boston, Massachusetts. National Marine Fisheries Service, Northeast Fisheries Science Center Ref Doc 02-01, Woods Hole, MA

Shepard AN, Auster PJ (1991) Incidental (non-capture) damage to scallops caused by dragging on rock and sand substrates. In: Shumway SE, Sandifer PA (eds) An international compendium of scallop biology and culture. World Aquaculture Society, Baton Rouge, LA, p 219-230

Watling L, Norse EA (1998) Disturbance of the seabed by mobile fishing gear: a comparison to forest clearcutting. Conserv Biol 12:1180-1197

Weiss HM (1995) Marine animals of southern New England and New York. Department of Environmental Protection, Hartford, CT

Witman JD, Sebens KP (1990) Distribution and ecology of sponges at a subtidal rock ledge in the central Gulf of Maine. In: Rutzler K (ed) New perspectives in sponge biology. Smithsonian Press, Washington, DC, p 391-396 